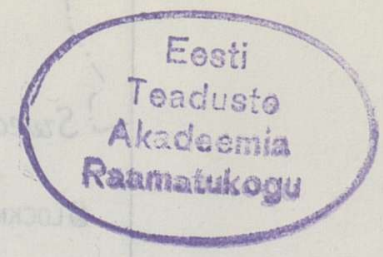

UDC $523.681 .8(474.2+487)$

\author{
Maurits LINDSTRÖM*, TOM FLODÉN*, Väino PUURA**, \\ and Kalle SUUROJA***
}

\title{
THE KÄRDLA, TVÄREN, AND LOCKNE CRATERS - POSSIBLE EVIDENCES OF AN ORDOVICIAN ASTEROID SWARM
}

Abstract. Comparisons of crater infill of the Middle Ordovician (Idavere) impact craters of Kärdla (NW Estonia), Tvären (SE central Sweden), and Lockne (NW central Sweden) have shed new light on asteroid impact events in epicontinental seas, calling also for new diversified terminology. The three craters are interpreted as having resulted from an asteroid swarm that hit Baltica in the early Idavere time.

The infilling of the $4 \mathrm{~km}$ wide Kärdla crater is used as type section. The Kärdla asteroid hit an area of relatively shallow water with a $140 \mathrm{~m}$ thick Cambro-Ordovician sequence covering the Precambrian crystalline basement. During an initial dry phase of the cratering event, crystalline-dominated autochthonous and subautochthonous breccias were formed. They are followed upwards by allochthonous coarse breccias, which are either dry phase slump and fallback breccias or were deposited during the initial part of backsurge. All these deposits show shock and thermal influence. During the water backsurge, coarse- to fine-grained breccias were deposited followed by a backsurge sandy turbidite, which becomes silty towards the top and is followed by post-impact fjord-type sediments.

The $2 \mathrm{~km}$ wide Tvären astrobleme formed in an area of somewhat deeper water and a sedimentary sequence limited to Ordovician limestone; no dry-phase deposits developed here. The autochthonous and sub-autochthonous crystailine breccias are followed upwards by a coarse backsurge breccia grading upwards into a gravelly backsurge turbidite which becomes sandy and finally silty towards the boundary of the post-impact fjord-type sediments.

As far as can be deduced until drillings become available, the infilling of the 7-8 km wide Lockne crater closely resembles that of the Kärdla crater. Target rocks consist of some $80 \mathrm{~m}$ of Cambrian shales and Ordovician limestone. On the crushed basement of the crater, crystalline Tandsbyn breccia, equivalent to the sub-autochthonous, slump, and fallback breccias of the dry phase of Kärdla, occurs. The backsurge is represented by Lockne breccia and the backsurge turbidite by the so-called Loftarsten greywacke unit.

Recent discoveries and new insights concerning the Ordovician impact craters formed in marine environments in Sweden have shed light on the significance of the $4 \mathrm{~km}$ wide crater structure at Kärdla on northern Hiiumaa Island, Estonia, which likewise formed at sea (Fig. 1). The genetic subdivision of the Kärdla crater infill proves to be applicable to the Swedish craters, too, although size and water-depth dependent differences must be considered. In order to compare and discuss the details in the development of small and medium-sized impacts in epicontinental shelf seas, a diversified terminology is introduced using the Kärdla crater infill as type section (Figs. 2 and 3 ).

\footnotetext{
* Stockholms Universitet (Stockholm University). Kungstensgatan 45, S-106 91 Stockholm. Sverige.

** Eesti Teaduste Akadeemia Geoloogia Instituut (Institute of Geology, Estonian Academy of Sciences). EE0105 Tallinn, Estonia pst. 7. Estonia.

*** Eesti Geoloogiakeskus (Geological Survey of Estonia). EE0101 Tallinn, Pikk 67. Estonia.
} 


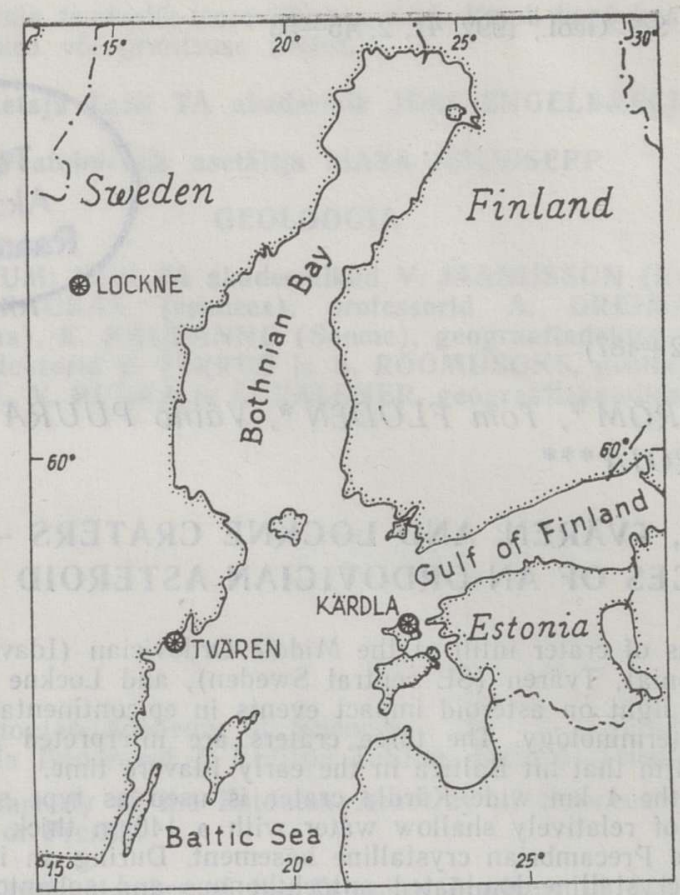

Fig. 1. Location of craters attributed to the Idavere (Middle Ordovician) asteroid swarm.

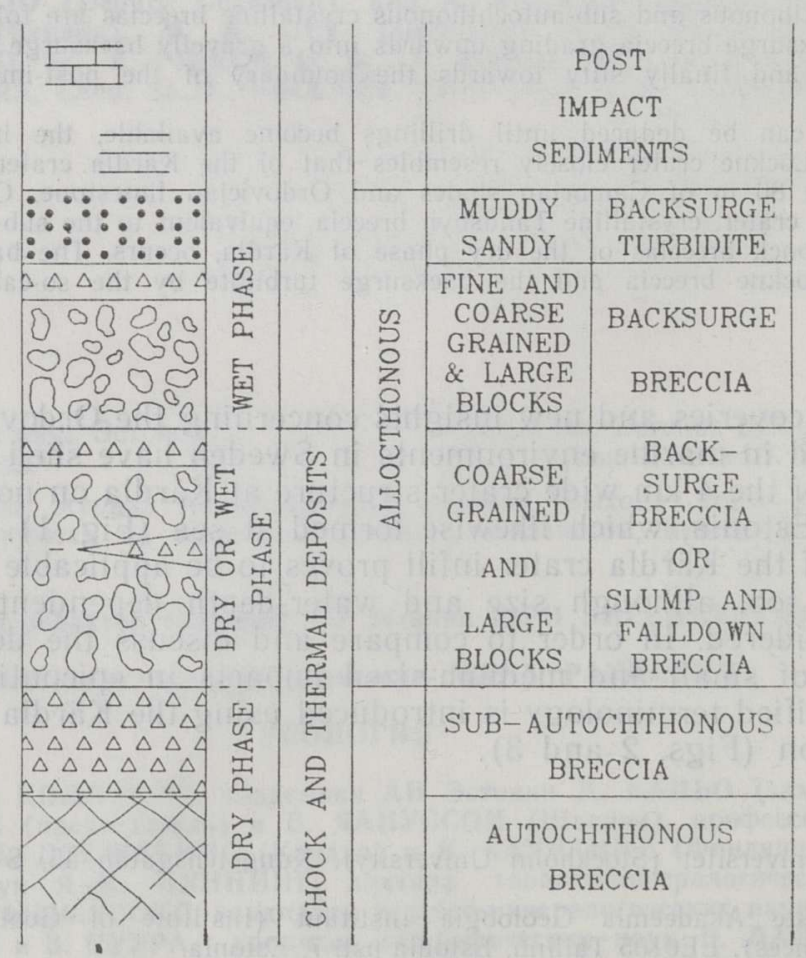

Fig. 2. Typical crater infill of impacts in epicontinental seas. 


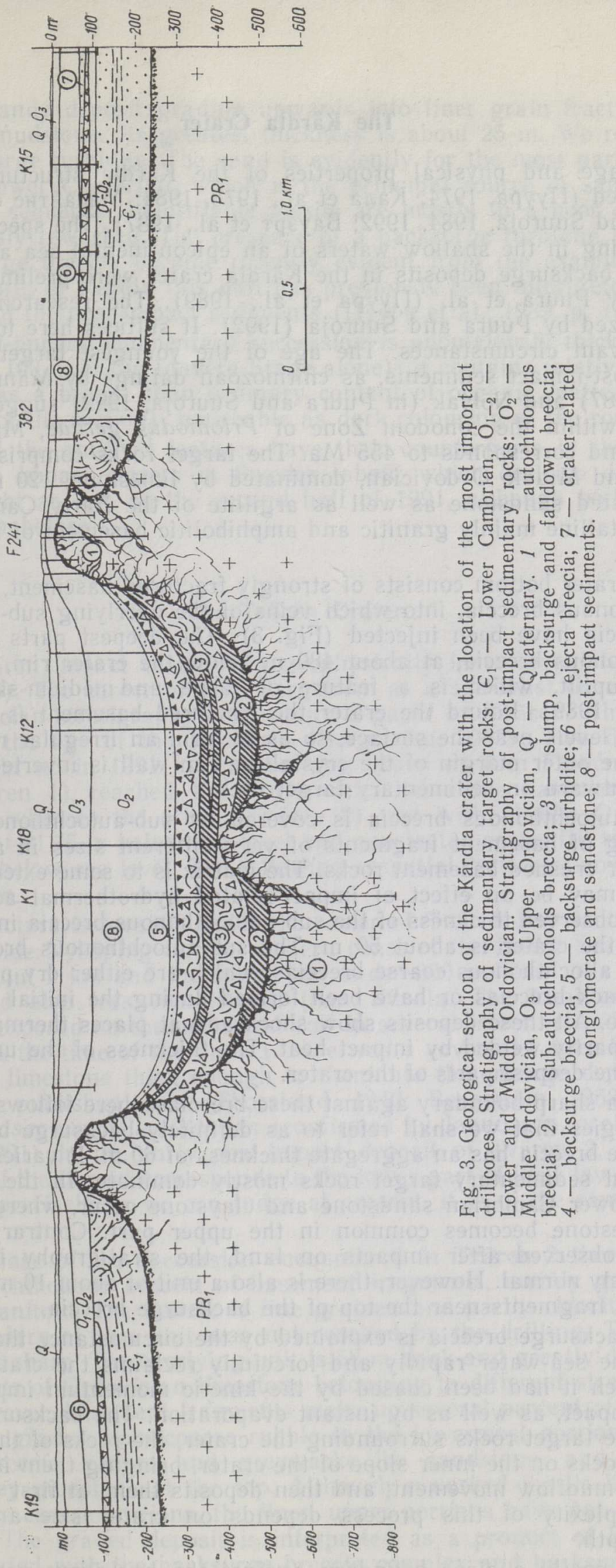


The age and physical properties of the Kärdla structure are well established (Пуура, 1974; Кала et al., 1978, 1984; Масайтис et al., 1980; Puura and Suuroja, 1984, 1992; Бауэрт et al., 1987). The specific process of cratering in the shallow waters of an epicontinental sea and the presence of backsurge deposits in the Kärdla crater were preliminarily described by Puura et al. (Пyypa et al., 1989). The research history is summarized by Puura and Suuroja (1992). It suffices here to indicate a few relevant circumstances. The age of the youngest target rocks and oldest post-impact sediments, as chitinozoan datings by Männil (Бауэрт et al., 1987) and Nõlvak (in Puura and Suuroja, 1992) suggest, is early Idavere within the conodont Zone of Prioniodus gerdae, Middle Ordovician, and corresponds to $455 \mathrm{Ma}$. The target rocks comprised $20 \mathrm{~m}$ of Lower and Middle Ordovician, dominated by limestone, $120 \mathrm{~m}$ of poorly consolidated sandstone as well as argillite of the Early Cambrian age, and crystalline mainly granitic and amphibolitic basement of the Proterozoic age.

The crater bottom consists of strongly fractured basement, here called autochthonous breccia, into which veins of the overlying sub-autochthonous breccia have been injected (Fig. 3). The deepest parts of the subautochthonous breccia, at about $480 \mathrm{~m}$ below the crater rim, surround a central uplift, which is a feature of large and medium-sized craters (Melosh, 1989). Round the crater the fractured basement is elevated to different levels near the surface, so as to form an irregular rim wall. In places the outer margin of the crystalline rim wall is inverted and overthrust outward on sedimentary target rock.

The autochthonous breccia is covered by sub-autochthonous breccia consisting of basement fragments of very different sizes in a matrix of even finer crushed basement rocks. The matrix is to some extent chloritized; this may be an effect of impact-related hydrothermal activity. The greatest observed thickness of the sub-autochthonous breccia in the deeper parts of the crater is about $50 \mathrm{~m}$. The sub-autochthonous breccia is covered by allochthonous coarse breccias, which are either dry phase slump and fallback breccias or have been formed during the initial part of the backsurge. All these deposits show shock and at places thermal influence and are partly welded by impact heat. The thickness of the unit is up to $90 \mathrm{~m}$ in the deepest parts of the crater.

With a sharp boundary against these breccias, there follows a complex of lithologies that we shall refer to as definitely backsurge breccia. The backsurge breccia has an aggregate thickness of $60 \mathrm{~m}$. It varies in composition, but sedimentary target rocks mostly dominate. In the lower part clasts, Lower Cambrian sandstone and claystone occur, whereas Ordovician limestone becomes common in the upper part. Contrary to ejecta breccias observed after impacts on land, the stratigraphy is thus approximately normal. However, there is also a unit of about $10 \mathrm{~m}$ on mainly basement fragments near the top of the backsurge breccia.

The backsurge breccia is explained by the circumstance that after the impact the sea-water rapidly and forcefully reclaims the crater territory from which it had been chased by the kinetic momentum imparted to it by the impact, as well as by instant evaporation. The backsurging water erodes the target rocks surrounding the crater, the rocks of the rim wall, and the rocks on the inner slope of the crater, bringing them into suspension and mudflow movement, and then deposits them, at first chaotically. The complexity of this process depends on crater size and original water depth.

With mostly a clear boundary against the backsurge breccia, there 
follows a sandy deposit grading upwards into finer grain fractions and ultimately mudstone. Its greatest thickness is about $25 \mathrm{~m}$. We refer to it as a backsurge turbidite. The sand is evidently for the most part derived from the Lower Cambrian, which is the principal source of sand in the target rock sequence. Identifiable fossils are mostly in a poor condition and obviously reworked. The presence of a backsurge turbidite following the backsurge breccia became recently evident from the examination of Tvären 2 core; in Kärdla this unit has previously been interpreted as the basal part of the post-impact sediments (Пуура et al., 1989, p. 159).

The post-impact sedimentary succession is anomalously thick (locally as much as $100 \mathrm{~m}$ of the Idavere Stage alone); it contains relatively much clay and has a bigger than ordinary content of organic matter (in the lower part of the section), noticeable as dark colouring of the rock.

Many of the outlined features have their counterparts in the Tvären and Lockne impact craters in Sweden, about which decisive data have come to light as late as the second half of 1991, although both craters were known before.

\section{The Tvären Crater}

The Tvären impact crater was geophysically investigated by Flodén et al. (1986). The career of Stig Bergström as a specialist on conodonts and Ordovician stratigraphy began with a paper on Tvären, which helps to identify the age of the structure (Bergström, 1962). Two drill-cores were brought up in 1991 by the working group of Tom Flodén. One of them (Tvären 1) reached the Proterozoic crystalline basement of the crater rim, whereas the other (Tvären 2) met with Middle Ordovician sediments at $81.75 \mathrm{~m}$ below sea level and penetrated crater fill to a depth of $224.4 \mathrm{~m}$ below sea level. The following essential facts can now be said to be known.

The structure is located under the water of Tvären Bay in the archipelago outside Nyköping on the western coast of the Baltic Sea. Its diameter is about $2 \mathrm{~km}$ and the depth just under $300 \mathrm{~m}$. Thus, the crater is smaller and also less complicated than Kärdla. The local crystalline bedrock is exposed on the mainland and in several islets around the bay. However, at the time of the impact there was a cover of Lower to Middle Ordovician limestone thick enough to dominate the resurge deposits. To judge from published data (Thorslund, 1940; Bergström, 1962) and a find of Neoasaphus cf. ludibundus (confirmed by Jaanusson, oral communication, 1991) in the early post-impact deposit of Tvären 2, the most likely age of the impact corresponds to the lower part of the Idavere Stage, that is, as precisely as we can judge at present, it is of the same age as the Kärdla crater.

At the base of the succession encountered in Tvären 2 there is $5 \mathrm{~m}$ of sub-autochthonous breccia of basement fragments, mainly gneiss and potassic granitoid. The matrix is fine grained and partly chloritized. The lower boundary of this unit was not reached by the drilling. The upper boundary is sharp. The overlying unit is $58 \mathrm{~m}$ thick and greatly dominated by fragments of Ordovician limestone belonging to different stratigraphic levels. However, basement fragments make up several percent of the rock. The unit is graded from coarse rubble in the lowermost portion through gravelly breccia, coarse and greywacke-like sandstone, and siltstone to light grey mudstone at the top. Although reworked fossils have been found in the coarse portions, the finer, upper portions have not yet yielded fossils. The graded deposit is interpreted as a product of backsurge and is equated with the backsurge breccia complex and backsurge turbi- 
dite of Kärdla. Owing to the uncomplicated bottom topography of Tvären, its smaller size, and possibly greater water depth, the backsurge deposit is simple, consisting of a single giant turbiditic layer.

Post-impact fossiliferous sedimentation at Tvären, represented by $80 \mathrm{~m}$ of grey, carbonatic mudstone with scattered laminae and lenses of limestone in Tvären 2, is inferred to have taken place under fjord-like conditions. That is, the isolated deep hole in the sea-bed developed for much of the time as relatively immobile water mass with a tendency toward hypoxia. The evidence consists of dark sequences with relatively high organic content. Mudslides from the crater flank caused some deformed bedding and occasional turbiditic beds and laminae.

\section{The Lockne Crater}

The Lockne impact crater on the Caledonian front of central Sweden (Lindström et al., 1991) is the largest of the three craters that are dealt with in this paper. It has a diameter of $7-8 \mathrm{~km}$ and is accordingly complex. Its geology has most recently been described by Lindström and Sturkell (1992). Because no drilling has been carried out, the deep structure is virtually unknown, but general features can be deduced from the surface geology and comparisons with the two craters just described. Target rocks are granitoids, schists, and dolerite of the Proterozoic age with a roughly $80 \mathrm{~m}$ thick cover of Cambrian and Ordovician. The Cambrian of the area essentially consists of about $30 \mathrm{~m}$ of Middle to Upper Cambrian soft, bituminous, black shale. The dominant lithology of the $50 \mathrm{~m}$ of Ordovician is bedded orthoceratite limestone; its age is Tremadoc to earliest Idavere.

On the crushed (low-resistivity) basement there rests today a widely distributed breccia of basement rocks including melt rock of the local basement, named Tandsbyn Breccia by Lindström and Sturkell (1992). Occurrences of this breccia are widely scattered in the area, but its continuous exposure appears to be confined to the crater area, which has its centre just to the northwest of Lake Locknesjön. The Tandsbyn Breccia corresponds to the sub-autochthonous and the possible slump and fallback breccias of Kärdla. Its boundary against the overlying backsurge deposits is sharp.

The backsurge breccia complex is represented by the Lockne Breccia, which mainly consists of orthoceratite limestone, although it also contains much basement material and major inclusions, of olistolith dimensions, of Tandsbyn Breccia. The Lockne Breccia was dated by Simon (1987a) as belonging to the Prioniodus gerdae conodont zone, that is, lower Idavere Stage. It is one of the most widely distributed lithologies of the area, its two remotest occurrences being situated at about $65 \mathrm{~km}$ from each other. At these distances the thickness can be measured in tenths of centimetres instead of tenths of metres, as at Lockne.

Simon (1987a), following Lindström et al. (1983), regarded the Lockne Breccia as a complex of debris flows, formed, presumably, as a consequence of crustal unrest in the early Idavere time. This interpretation was adhered to by Lindström et al. (1991), even after they established the Tandsbyn Breccia as an impact breccia. The conclusion then became that the clean separation between the Tandsbyn Breccia and the Lockne Breccia, as well as the occurrence of inclusions of the former within the latter, indicated a considerable lapse of time between the impact and the gravity flows leading to the formation of the Lockne Breccia. The impact was dated to the early Middle Cambrian because crushed basement granite of the outer flank of the rim wall rests in an inverted position on early 
Middle Cambrian alum shale at Nordanbergsberget (Simon, 1987b; Lindström et al., 1991; Lindström and Sturkell, 1992) and because the regional stratigraphy appeared to permit this date as well as the early Idavere age given by Simon (1987a), but no others. Comparison of Lockne with Kärdla and Tvären now makes it obvious that the Middle Cambrian date was a mistake, and that the proper age is Simon's dating of the Lockne Breccia as early Idavere (Simon, 1987a).

The Lockne Breccia is overlain by so-called Loftarsten, which is a turbiditic greywacke with much carbonate fragments as well as sandsized clasts of impact melt. The Loftarsten unit is a typical backsurge turbidite. In places it grades downwards into coarse Lockne Breccia. Mostly, however, the boundary against the Lockne Breccia is sharp.

\section{Discussion}

The craters at Kärdla, Tvären, and Lockne were created, possibly simultaneously, in an Ordovician epicontinental sea. Although each one of the craters is unique due to differences in size, water depth, and the entities of the local bedrock sequence, it is possible to discuss a lithological type section that contains the essentials of marine impacts in shelf sea environments. Our comparison of the craters further suggests the use of diversified terminology in dealing with these craters (Fig. 2).

Unless a rare coincidence has led to three discrete impact events, on slightly different occasions but within a geologically short time, within a distance of about $750 \mathrm{~km}$ of one another, the three impacts described above belong to an asteroid swarm that hit Baltica in the early Idavere time. Because the target rocks provide different chemical standards, it should in this case be possible to find out the chemistry of the meteorite swarm rather precisely.

The comparison of the three impacts permits some generalizations to be made about impacts in shelf seas. During the initial phase of the very fast cratering process, water will be chased from the impact site and the crater will be essentially dry. Therefore, conditions are the same as for impacts on land. A slump and fallback breccia can form in the final stage of this process, without interference from water.

Kärdla is typical in this respect, located in a comparatively shallow zone near the thinout area of the early Idavere sea. Thus, Kärdla has a rather long dry phase permitting a diversified rock unit to be deposited. In comparison, Tvären was located in an area of deeper water, which led to an extremely short, or nonexisting, dry phase. In the Lockne crater, typical dry phase deposits are again met with, repeating the units found at Kärdla.

Water kinetically expelled from the site will erode the surrounding deposits. When the backsurge takes place it will carry at least three categories of solids to the crater, viz. clasts eroded by expelled water masses, impact ejecta (which will not form an ejecta blanket structurally identical to blankets formed on land), and clasts eroded by the backsurge from the surroundings, the rim walls, and the inside of the crater. Especially in large craters, the backsurge will be a complex process with water masses advancing from different directions and occasionally crossing the paths of one another. Complications are especially obvious at Lockne, but are not negligible at Kärdla either.

At the stage when sea-water has reached its normal level above the crater, the quantity of matter suspended in it will still be considerable. In turbidite fashion, the settling of the coarsest suspensate fractions will already have begun while movement remains strong, but a graded deposit 
will continue to form for as long as there is ample suspensate. This process is responsible for deposition of the backsurge turbidite.

After backsurge deposition the crater will remain as a topographically confined patch of sea floor that is much deeper than the surroundings. The principal effects that this circumstance will have on post-impact sedimentation is that more sediment will be trapped than in the surrounding areas and that conditions will frequently tend to become hypoxic. Thus, relatively thick, dark muds will be typical sediments.

\section{R E F E R E N C E S}

Bergström, S. M. 1962. Conodonts from the Ludibundus limestone (Middle Ordovician) of the Tvären area (S. E. Sweden). - Arkiv för Mineralogi och Geology, 3., $1-61$.

Flodén, T., Tunander, P. and Wikman, F. E. 1986. The Tvären Bay structure, an astrobleme in southeastern Sweden. - Geologiska Föreningens i Stockholm Förhandlingar, 108, 3, 225-234.

Lindström, M., Simon, S., Paul, B. and Kessler, K. 1983. The Ordovician and its mass movements in the Lockne area near the Caledonian margin, central Sweden. Geologica et Palaeontologica, 17, 17-27.

Lindström, M., Ekvall, J., Hagenfeldt, S. E., Säve, B. and Sturkell, E. F. F. 1991. A wellpreserved Cambrian impact exposed in Central Sweden. - Geol. Rundschau, 80, $1,201-204$.

Lindström, M. and Sturkell, E. F. F. 1992. Geology of the Early Paleozoic Lockne impact structure, Central Sweden. - Tectonophysics. (In press.)

Melosh, H.J. 1989. Impact cratering, a geological process. - In: Oxford Monographs on Geology and Geophysics 11. Oxford University Press, New York.

Puura, V., Suuroja, K. 1984. Kärdla kraater - maapõue varjatud uunikum. - Eesti Loodus, 9, 595-565.

$\checkmark$ Puura, V. and Suuroja, K. 1992. Ordovician impact crater at Kärdla, Island of Hiiumaa, Estonia. - Tectonophysics, Elsevier. (In press).

Simon, S. 1987a. Stratigraphie, Petrographie und Entstehungsbedingungen von Grobklastika in der autochthonen, ordovizischen Schichtenfolge Jämtlands (Schweden). Sver. Geol. Unders., Ser. C815.

Simon, S. 1987b. Caledonian deformation of basement in the Lockne area, Jämtland, central Sweden. - Geol. Fören. Stockholm, Förhandl., 109, 269-273.

Thorslund, P. 1940. On the Chasmops Series of Jämtland and Södermanland (Tvären). Sver. Geol. Unders., Ser. C436, 1-191.

Бауэрт Х. А., Мянниль Р. М., Сууроя К. А. 1987. О времени образования Кярдлаского кратера. - In: Тез. докл. Всесоюз. метеоритной конф., 1, Москва, 48.

Кала Э. А., Пуура В. А., Сууроя К. А. 1978. О Кярдлаской кратерообразной структуре на острове Хийумаа. - In: Локальные структуры Белоруссии и Прибалтики. Вильнюс, Мокслас, 88-91.

Кала Э., Пуура В., Сууроя К. 1984. Главные черты строения Кярдлаского погребенного кратера. - Изв. АН ЭССР. Геол., 33, 1, 1-7.

Масайтис В. П., Данилин А. Н., Мащак М. С., Райхлин А. И., Селивановская Т. В., Шаденков T. Н. 1980. Геология астроблем. Ленинград, Недра.

Пуура В. А. 1974. Структура южного склона Балтийского щита. Автореф. канд. дис. Таллинн.

Пуура В. А., Кала Э. А., Сууроя К. А. 1989. Строение астроблемы Кярдла. Метеоритика, 48, 150-161. 


\section{KÄRDLA, TVÄRENI JA LOCKNE KRAATRID KUI VIIDE ORDOVIITSIUMI ASTEROIDIPARVELE}

Viimaste uuringutega on tuvastatud Eestis ja Rootsis ainult $750 \mathrm{~km}$ läbimõõduga alal asuva kolme kraatri samaaegne teke keskordoviitsiumis Vara-Idavere eal niivõrd täpselt, kui seda võimaldab paleontoloogiline meetod. Seega on võimalik, et Kärdla (diameeter $4 \mathrm{~km})$, Tväreni $(2 \mathrm{~km})$ ja Lockne $(7-8 \mathrm{~km})$ kraater tekkisid samasse asteroidiparve kuuluvate meteoriitide löögi tagajärjel. Omaaegse mandrilava madalmeres moodustunud kraatrite kõrvutava uurimise tulemused võimaldavad teha üldistusi, mis käsitlevad suhteliselt madalaveelises keskkonnas moodustunud kraatrite iseärasusi.

Meteoriidi plahvatusel madalaveelises keskkonnas vesi aurustub ja tõrjutakse tekkivast kraatrist eemale. Kraatritekke varasel staadiumil löögi- ja kuumusmoondele allunud kivimid moodustavad kraatripōhja purustatud kivimite autohtoonse bretša, seda katva subautohtoonse bretšakihi ning külgedelt tagasi libisevatest (tormavatest) ja öhust sadestuvatest purustatud ja segatud kivimitest allohtoonse bretšakihi. Plahvatuse mõjul algul eemale ja seejärel tagasi tormav vesi erodeerib merepõhja ning kannab kaasa sorteerimata purdmaterjali, mis on haaratud merepõhjast, kraatrivälisest puistest, kraatri ring vallist' ja sisemusest. Tagasitormavast, erakordselt palju tahket ainet sisaldavast suspensioonivoost algab kraatris uus sedimentatsioonifaas (veeline sedimentatsioon), mille algul on moodustunud ülisuuri kivimiplokke sisaldavad allohtoonsed bretšad ning loppuks kujunenud liivakad ja mudajad turbidiidid. Selles materjalis kohtab harva ka kivimite löögi- ja kuumusmoonde ilminguid.

Kummagi sedimentatsioonifaasi täielikkus sõltub basseini sügavusest. Esimese, kuiva faasi allohtoonse bretša rikkalikuks väljakujunemiseks peab vesi olema piisavalt kaugele tõrjutud. Kuiva faasi kivimid on sarnased maismaal tekkinud kraatrite bretšadega. Veelise faasi allohtoonsed bretšad ja turbidiidid tekivad vaid meteoriidi löögil veekogu põhja. Nende suurim maht tekib veekogu teatava optimaalse sügavuse korral. Kärdla kraatris on rikkalikult esindatud mõlema faasi kivimid, Tväreni kraatris on seni teada täielikum veeliste (mereliste) bretšade ja turbidiitide läbilõige, Lockne kraatri litoloogilised kompleksid on seni nõrgalt uuritud.

\section{Маурищ ЛИНДСТРЕМ, Том ФЛОДЕН, Вяйно ПУУРА, КалЛе СУУРОЯ}

\section{КРАТЕРЫ КЯРДЛА, ТВЭРЕН И ЛОКНЕ - ВОЗМОЖНЫЕ СВИДЕТЕЛЬСТВА АСТЕРОИДНОГО РОЯ В ОРДОВИКЕ}

Последними исследованиями доказано, что кратер Кярдла на территории Эстонии и кратеры Твэрен и Локне на территории Швеции, удаленные друг от друга не более чем на 750 км, имеют одинаковый биостратиграфический возраст раннеидавереское время, средний ордовик. Все три кратера образовались в условиях мелководного шельфа, в результате чего сформировались специфические, рожденные взрывом литологические комплексы, прежде всего брекчии - ранние сухой (субаэральной) стадии и поздние водной (аквагенной) стадии. Объем и состав этих комплексов зависят, помимо прочих факторов, от глубины воды. Рассматривается терминология литологических комплексов. 